\title{
Droopy shoulder syndrome と頝椎側面
}

$$
\mathrm{X}-\mathrm{P} \text { の関連について }
$$

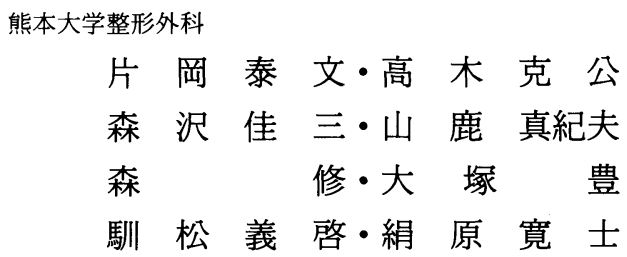

\section{The Relation between Droopy Shoulder Syndrome and Lateral View of Cervical Spine X-rays}

by

\section{Yasufumi Kataoka, Katsumasa Takagi, Keizo Morisawa, Makio Yamaga, Osamu Mori, Yutaka Ootuka, Yosihiro Narematu and Kanji Kinuhara}

Department of Orthopaedic Surgery,

Kumamoto University Medical School

L. J. clein and T. R. swift reported Droopy Shoulder Syndrome (DSS). The patients with DSS had various symptoms and signs. And they demonstrated that the second thoracic spinal body of these patients, was visible in the lateral view of cervical spine X-rays. In this report we studied the relation between the symptoms of DSS and the visibility of the second thoracic spinal body in cervical spine $\mathrm{X}$-rays. Therefore, we examined the lateral view of cervical spine $\mathrm{X}$-rays in 500 cases that came to our department with various disorders between 1988 and middle of 1989 . In 52 cases, $10.4 \%$ of the total, we could see the second thoracic spinal body. So we did make inquiries about the symptoms of DSS to these cases, and got 42 answers from them. 15 cases of the 42 (36\%) had the symptoms of DSS, but other cases had no symptons. We think this rate is very high. But we had had some patients with DSS whose second spinal body were not visible. Because of these results we think the visibility of the second spinal body in cervical spine X-rays is only one of the signs of DSS. And 11 of the 15 cases, who had the symptoms of DSS, were diagnosed as TOS. Therefore, we should have a doubt about combined DSS in female patients with TOS.

$$
\text { はじめに }
$$

Droopy Shoulder Syndrome (以下 DSS と省略)は, L. J. Clein (1975) や T. R. Swift (1984) によって報告 された疾患概念で, Clein は肩の下がった, 長い首の中 年女性で，頝部〜上肢にかけての痛みを訴え，榔状態 を呈することが多い疾患であると報告し, 頝椎側面 X -Pにおいて第 2 胸椎椎体が見えることを指摘している $(\text { 図 } 1)^{1) 3)}$.
Swift と, TOS と DSS の関連に着目し, 以下の 7 項 目をDSS の特徵として上げている.1)“Droopy”なな で肩であり Swan neck 様の長い首が特徽的である.2) 䅡部・肩甲帯・胸部・上肢㧍よび手の痛みを主訴とし ている. 3) 上肢の下方牽引で症状が増悪し, 支持によ り改善する．4）ほとんどが女性．5）血管・神経系お よび電気生理学的に異常を認めない，6)腕神経叢部に Tinel's sign がある. 7)䅡椎側面 X-P にて, 第 2 胸椎 椎体が見える。 


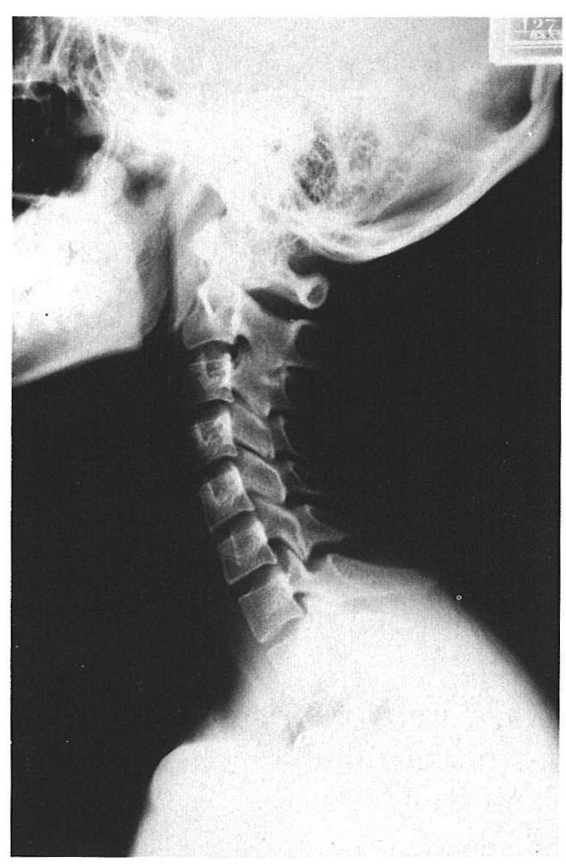

図 1 DSS での頝椎側面 X-P $\mathrm{Th}_{2}$ 椎体が見える.
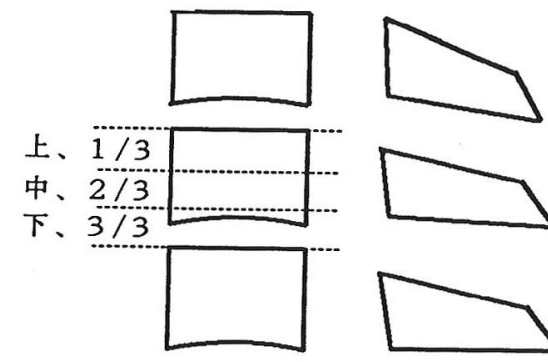

図 2 〔可視椎体判定区分〕

病態としては，圧迫によって生じる TOS と異なり， 腕神経叢に対する牽引力によって起こる疾患と推測さ れている。

また, Swift は, DSS は TOS と混同されて手術され ることがあり,TOS 手術不良例の一因となっているた め，手術を行うべきでないと警告している ${ }^{34)}$.

ところで, Clein や Swift が指摘した, DSS の特徴の 一つである,頝椎側面 X-P にて第 2 胸椎椎体が見える という所見に関し,彼らはDSS の症状の発現との関連 性についての検討を行っていない。

そこでわれわれは, 当科外来にて, 䝺椎 X-P 検查を 行った患者について検討してみた。
表 1 《アンケートチェック項目》

名前 , 年令 才, 性(M.F),現疾患

(診 断 項 目)

1)腕を下げていると,手や腕が舫れたり急くなりますか？

2)重い物を持つと, 痺れや怘さがひどくなりますか？

$(\mathrm{Y}, \mathrm{N})$

3)时を着いたり腕を組むと, 症状が軽くなりますか？

$(\mathrm{Y}, \mathrm{N})$

4)手や腕の痺れや急さは貴方にとって苦痛ですか?

$(\mathrm{Y}, \mathrm{N})$

5)肩凝りや, 胸や背中の痛みが有りますか?

$(\mathrm{Y}, \mathrm{N})$

6) 首と鎖骨の間を押さえると，痛みが有りますか？

7)*YESの場合, 痛みは腕の方に響きますか?

〔関 連 項 目〕

8)なで肩だとか，首が長いと思いますか？（Y,N)

9)猫背とか，姿勢が悪いと思いますか？ (Y,N)

10)小さなことでも気になるほうですか？ (Y,N)

11）重い物を持つと，肩が下に拔ける感じが有りますか?

$(\mathrm{Y}, \mathrm{N})$

\section{症例および方法}

当科外来にて,昭和 63 年〜平成元年の約一年半に䅡 椎 X-P 検查を行った, 500 症例の側面像に扔ける可視 椎体レベルを（図 2 ）で示すように 3 段階に分けて評 価した。

そして, $\mathrm{Th}_{2}$ 椎体が確認できた症例における症状に ついて,外来扔よび電話アンケートを用いて調べ, DSS の症状との関連性について検討ししてみた。

アンケートは $1 \sim 7$ の診断項目と $8 \sim 11$ の関連項目 について行っている(表 1).

診断 7 項目中 6 項目以上の所見があった場合のみ, DSSの可能性が高いと考えて，DSS 陽性と判定した。

なお，DSS 陽性と判定された症例の中には，すでに DSS の診断が付いている症例も含まれており,これら の症例ではDSS の確定診断として腕神経叢造影を行 い,DSS に特徵的な牽引所見が確認されている(図 3 ).

\section{結果}

可視椎体の平均は, $\mathrm{Th}_{1}$ 椎体中央士 1 椎体幅であり, 500 症例中， $10.4 \% ， 52$ 例において， $\mathrm{Th}_{2}$ 椎体を見る ことができた（図 4 ).

この内, 連絡および判定不能であった 10 例を除く 42 例にたいしてアンケートを行っている。11例は直接外 来で, 残り 31 例は電話連絡に選るものであった。

DSS 陽性所見は 42 例中 15 例， $36 \%$ に認められた。 


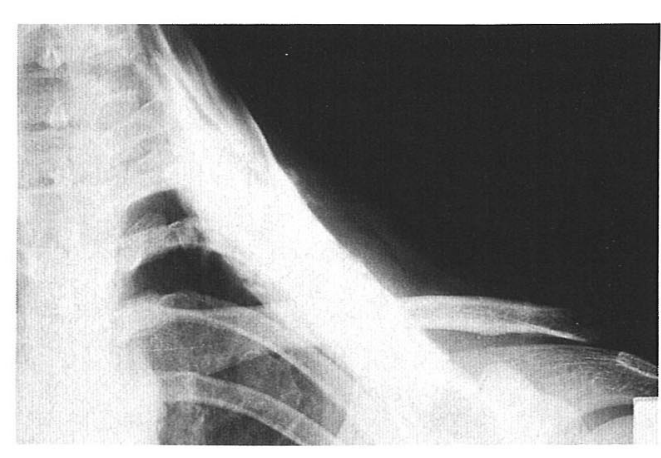

図 3 立位上肢下垂時一腕神経叢率引所見 神経叢が直線的に造影されている。

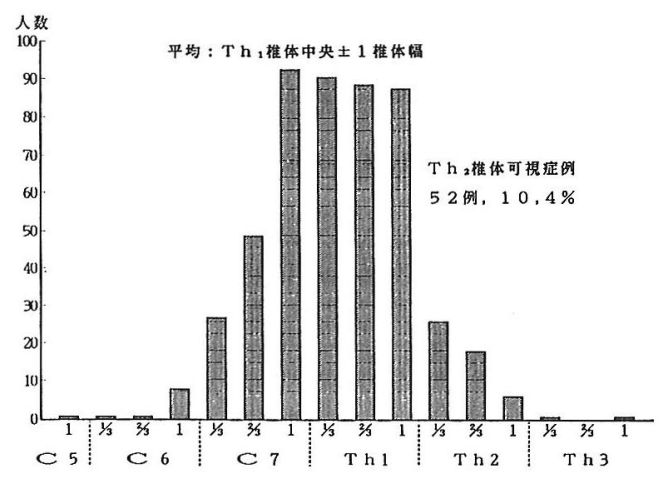

図 4〔500症例における可視椎体分布〕

なお,今回のアンケート以前に DSS の症状を認めて いた症例が 11 例あり，4例のみがアンケートで判明し た症例である。

また，診断 7 項目における陽性項目数は，DSS 陽性 群で, $6.8 \pm 0.4$ 項目, DSS 陰性群で $1.5 \pm 1.2$ 項目と, まったく異なる 2 集団に分類可能であった。

現疾患との関連において, DSS 陽性群では圧倒的に TOS が多く, $73 \%$ に合併を認め, DSS 単独は 2 例 13 \%であった。

これに対して, DSS 陰性群では TOS の症例は 1 例も なく, 変形性頝椎症 $33 \%$, 頝部痛 $33 \%$, 頝椎捻挫 15 \%などの疾患が認められた（表 2 ）。

関連項目に関して, DSS 陽性群と陰性群の比較では, 陽性群になで肩が多く, 不良姿勢を示す者も多かった。

また，精神面での榃状態に関しては，両群に大きな 差は認めていない。

肩の下方不安定感に関しては, DSS 陽性群で 53 \%と 非常に高い数值を示し, 陰性群の $11 \%$ と有意な差が有 った（表 3 ).
表 2 〔アンケート結果とカルテ現疾患名〕

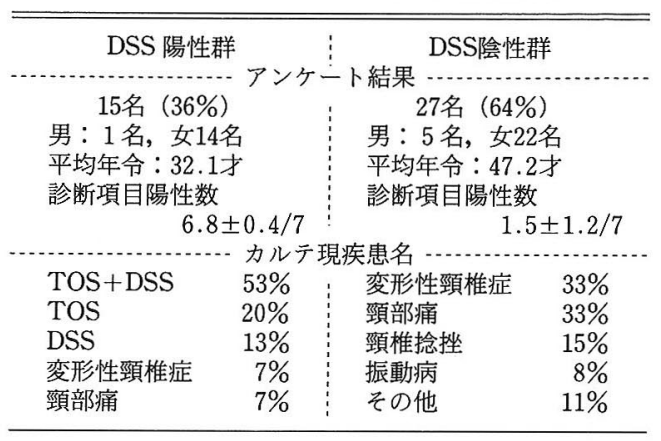

表 3 〔アンケート関連項目陽性率〕

\begin{tabular}{|c|c|c|}
\hline DSS- & 陽性群 & 陰性群 \\
\hline $\begin{array}{l}\text { （）な゙肩だとか, 首が長いと } \\
\text { 思いますか？ }\end{array}$ & $80 \%$ & $25 \%$ \\
\hline $\begin{array}{l}\text { (O)猫背とか, 姿勢が悪いと思 } \\
\text { いますか? }\end{array}$ & $73 \%$ & $44 \%$ \\
\hline $\begin{array}{l}\text { (0)小さなことでも気になるほ } \\
\text { うですか? } \\
\text { （）重い物を持つと，肩が下に }\end{array}$ & $67 \%$ & $51 \%$ \\
\hline 抜ける感じが有りますか？ & $53 \%$ & $11 \%$ \\
\hline
\end{tabular}

\section{考察}

今回のアンケートで, $\mathrm{Th}_{2}$ 椎体を認める 42 症例中, 15 例, $36 \%$ \%いう高い頻度で DSS 症例が認められた。 しかし， $\mathrm{Th}_{2}$ 椎体が見られた症例でも，60\%以上の症 例では DSS の症状が認められなかった。

さらに，われわれは $\mathrm{Th}_{2}$ 椎体を認め無い症例の中に も, 首が長く見えDSS 様症状を示す者を数例経験して おり,これらの症例では腕神経丵造影で, いわゆるDSS 症例と同様な牽引所見を確認している。

以上より $\mathrm{Th}_{2}$ 椎体を認めることは, DSS の必須条件 では無く，典型例における一つの所見と考えられた。

また，今回の検討に扔いて， $\mathrm{Th}_{2}$ 椎体を認めた TOS 症例は, 全例 DSS 陽性群に含まれており, 少なくとも 首の長い，とくに女性の TOS 患者を見た場合は, DSS の合併を念頭に扔いて診断，治療を行うべきである。

さらに, 今回のアンケートでは, DSS 陽性群の $53 \%$ に肩関節下方不安定性を疑う所見を認めている。この 場合 DSS と同様に, 腕神経叢への牽引によって症状が 発現しうるため, DSS との鑑別が難しく，今後の検討 を要する. 今回の検討の結果, 腕神経叢への圧迫によ り生じる TOS と, 牽引によって起こるDSS および, 類似の牽引作用を示す肩関節下方不安定性との間にお 
ける関連性が浮かび上がってきた。

原因としては，肩甲带の不安定性や弛緩性が推測さ れるが，このことに関しては不明な点が多く, 今後さ らに症例を重ねて検討を加えていきたい.

\section{ま と め}

1. 頝椎側面 $\mathrm{X}-\mathrm{P}$ で, $\mathrm{Th}_{2}$ 椎体を認めることと DSS との関連について検討した。

2. $\mathrm{Th}_{2}$ 椎体を認めることは, DSS の必須条件では 無く，一所見と考えられた.

3. 首の長い, とくに女性の TOS 患者では, DSS の 合併を念頭におくべきである。

4. DSS と TOS および肩関節下方不安定性の関連 については, 今後の検討を要する.

\section{参考文 献}

1) Clein L. J.: The droopy shoulder syndrome.
CMAJA, $114:$ 343-344, 1976.

2）片岡泰文・他：TOSにおける腕神経叢造影と鎖骨下 動脈造影の比較検討. 整形外科と災害外科, 38 : (1) 308 $-311,1989$.

3) Swift T. R. : Nichols F. T.: The droopy shoulder syndrome. Neurology, $34: 212-215,1984$.

4) Takagi. K. et al. : Management of thoracic outlet syndrome. Arch Orthop Trauma Surg, 106: 78-81, 1987.

質 問福岡大学 高岸 直人

DSS に対する治療はどうしてますか.

\section{解 答 熊大 片岡 泰文}

現在適切な治療法が有りませんが，当科では装具を 用いた肩甲帯挙上を行っています．筋力増強も行って ますが十分な効果が得られていません. 